\title{
Analysis of the use of Accounting Information in Micro, Small and Medium Enterprises (MSMEs) Salt Farmers in the Coastal Area of Rembang Regency
}

\author{
Rikah $^{1}$ \\ \{rickah83@gmail.com ${ }^{1}$ \} \\ Sekolah Tinggi Ilmu Ekonomi YPPI Rembang, Central Java, Indonesia ${ }^{1}$
}

\begin{abstract}
In contrast to social-emotional communication, the amount of information exchanged has a gap. Based on these findings, we recommend that future studies formulate specific guidelines for pharmacists for treating patients with chronic disease with a short duration. The rapid development of science and technology has various impacts on various aspects, effects to the competition in the business world is becoming tougher. Accounting information can help MSMEs in making economic decisions for the achievement and sustainability of the business. Rembang Regency has a large number and area of smallholder salt farming in the coastal area which has the potential to be developed. This study aims to analyze accounting information on salt farmers MSMEs in the coastal area of Rembang Regency. The education, accounting training, company age, and information technology of the firm owner will all be considered in the analysis of accounting information utilization. This study uses a quantitative approach with descriptive investigation. A questionnaire was used to collect data. Purposive sampling was used with a total sample of 100 salt farmers MSMEs, and the data was analyzed using multiple linear regression with the SPSS program. The findings revealed that the majority of salt farmer MSMEs utilized accounting data in their operations. According to the findings, business owners, accounting training, and information technology all have an impact on the usage of accounting data.
\end{abstract}

Keywords: Accounting information systems, salt farmers, MSMEs

\section{Introduction}

The rapid advancement of science and technology has a wide range of consequences. One notable result is that corporate competition is growing more intense. Various sectors and business sizes are affected by this rivalry. Accounting data can assist MSMEs in making economic decisions that will help them achieve business success and sustainability. Rembang Regency has a large number and area of smallholder salt farming in the coastal area which has the potential to be developed. Salt is a local potential in Rembang Regency which has an important role in contributing to regional income which is quite large.

Small and medium businesses (SMEs) play a critical part in the nation's economic development and prosperity. According to data from Indonesia's Ministry of Cooperatives and SMEs, Indonesian MSMEs donated up to Rp. Indonesia's GDP is $\$ 8.573 .9$ trillion (at current prices). In 2018, Indonesia's GDP was Rp. MSMEs additionally employ 116,978,631 individuals, or 97 percent of the total volume; Indonesian workers contributed $57.8 \%$ to GDP 
in 2018 (MSMEs and Large Units). Until 2018, there were 64,194,057 Indonesian MSMEs, accounting for 99.99 percent of the country's total business units (Ministry of Cooperatives and SMEs, 2018). This percentage is expected to continue to increase in the coming years due to the improving economic growth in Indonesia. The tighter competition between MSMEs and large companies, MSMEs must seek competitive advantages that can help them minimize costs and maximize profits.

Explained that finance is a common problem faced by everyone. Everyone has to do with money, both as married individuals and unmarried individuals, individuals and companies. Often problems arise how to manage the finances that we have. Generally, the problem is not in the lack of income, but in the wrong habits of managing finances. Various kinds of other limitations faced by MSMEs ranging from educational backgrounds that do not know accounting or recording procedures, insufficient funds to hire accountants or buy accounting software to facilitate the implementation of accounting bookkeeping [1]. Furthermore, efforts to develop MSME firms confront a number of challenges, including a lack of education, a lack of understanding of information technology, the size of the business, and the lack of financial reporting reliability in the MSME entrepreneur environment. The inability to provide and use accounting information is a major element that causes challenges for small and medium-sized businesses and leads to their failure to grow [2]. From a management standpoint, the inability to provide and use accounting data is a flaw. This flaw is the primary reason why MSMEs fail to grow their enterprises. The capacity of the owner to produce and use accounting information is strongly reliant on his or her ability to use accounting techniques. Small businesses can be jeopardized by a lack of financial knowledge in management [3]. Deteriorating financial situations and a lack of accounting records will limit the company's ability to get vital information, making it more difficult for it to grow and even causing it to fail. Accounting information is a tool that users of accounting information, particularly business professionals, use to make decisions [4]. Accounting data is utilized for strategic planning, management oversight, and operational oversight. Statutory accounting information, budget accounting information, and supplementary accounting information were employed in this study based on the benefits to the users.

Previous academics in Yogyakarta did research on the impact of accounting information on small and medium enterprises. According to the Accounting Information System (AIS), Mind Your Own Business (MYOB), the majority of Small and Medium Enterprises in Yogyakarta have employed it in their operational activities [5]. The utilization of accounting information for SMEs in Yogyakarta is influenced by manager / owner education and business scale, but tenure in managing the company, company age, and manager / owner accounting training have no effect. The educational background of its management will also have an impact on their financial behavior. The utilization of accounting data is influenced by education level, firm size, length of business, and educational background. Simultaneously, it demonstrates that the usage of accounting information is influenced by the amount of education, educational background, firm tenure, business scale, and accounting understanding [2]. Based on the aforementioned issue, MSME actors in terms of accounting, as well as their developments, rely on current accounting data. So that it can make better decisions in the future. The researchers did a study named "Analysis of the Use of Accounting Information in Micro, Small and Medium Enterprises (MSMEs) Salt Farmers in the Coastal Areas of Rembang Regency" based on the importance of MSME accounting information. This study intends to assess the use of accounting information for salt farmers MSMEs in coastal areas of Rembang Regency, in accordance with the context and problem formulation. The education, accounting training, company age, and 
information technology of the firm owner will all be considered in the analysis of accounting information utilization.

\section{Method}

\subsection{Population and sample}

The participants in this study were salt farmers who owned MSMEs in Rembang Regency's coastal area. In Rembang Regency, there are 100 MSMEs salt farmers. The purposive sampling approach is used in this study, which is a sampling methodology with particular considerations directed at the criteria given, namely: 1) A registered MSME salt farmer in the Rembang Regency Department of Marine Affairs and Fisheries, 2) MSMEs in the Rembang Regency area, 3) MSMEs that are still active, 4) Registered in the Rembang Regency Cooperatives and UMKM Office, 5) Already established for 5 years, 6) Have a turnover of IDR 500,000 per day or IDR $10,000,000$ per month.

\subsection{Types and data collection}

Primary data is the sort of data used in this study. Using a questionnaire survey approach to collect the data needed to support this research. A questionnaire survey is a type of survey that involves the use of a research questionnaire. For a complete investigation of the characteristics of the population under study, the questionnaire is an effective data collection method. The research questionnaire was sent directly to salt farmer MSMEs in Rembang Regency's coastal area.

\subsubsection{Hypothesis testing}

\subsubsection{Validity test}

The validity test is said to be valid if the significance value is 0.05 or $5 \%$, which means that the data is certified legitimate if the significance value is 0.05 [6].

\subsubsection{Reliability test}

Reliability is a tool for assessing the validity of a questionnaire, and it serves as a predictor of the variables or constructs that will be studied. The level of stability or steadiness of a measuring device when assessing a symptom or occurrence is referred to as the reliability test. If a construct or variable delivers $>0.70$ or $70 \%$, it is said to be trustworthy [6].

\subsection{Classic assumption test}

The classical assumptions inherent in the regression model equation are also tested in this study so that the data utilized to test the hypothesis is free of classical assumptions [7]. These tests include [6]: 
- The purpose of the normality test is to see if the regression model, the dependent variable (dependent), and the independent variable (independent) all have a normal distribution. The Kolmogorov-Smirnov (K-S) normalcy test was utilized in this investigation, which looked at the significant probability of the variables. The variable is regularly distributed if the probability is significant $>0.05$.

- The purpose of the multicollinearity test is to see if the regression model established a relationship between the independent variables (independent). There should be no correlation between the independent variables in a decent regression model (independent). If the tolerance value is greater than 0.10 and the VIF value is less than 10 , the regression model is multicollinear.

- The autocorrelation test is used to see if there is a link between the confounding error in period $t$ and the error in period $t-1$ in a linear regression model. The regression results are deemed to be spared autocorrelation if the Durbin Watson value is between du d 4-du.

- The heteroscedasticity test determines whether there is an inequality of variance between the residuals of one observation and the residuals of another in the regression model. If the significance value is more than 0.05 , the model is not heteroscedastic.

\subsection{Data analysis method}

This research data analysis method uses the form of multiple linear regression equations which are formulated based on the developed hypothesis, namely as follows [8]:

$\mathrm{Y}=\mathrm{a}+\beta 1 \mathrm{X} 1+\beta 2 \mathrm{X} 2+\beta 3 \mathrm{X} 3+\beta 4 \mathrm{X} 4++\varepsilon$ (where $\mathrm{y}$ : Use of Accounting Information,

$\alpha$ : Constants, $\beta 1$ : Regression coefficients of Business Owner Education, $\beta 2$ :

Regression coefficient of Company Age, $\beta 3$ : Regression coefficients of Accounting Training, $\beta 4$ : Regression coefficients of Information Technology X1: Business Owner Education, X2: Business Owner Education, X3: Accounting Training, and X4: Information Technology.

\section{Results and Discussions}

\subsection{Results}

\subsubsection{Classic assumption test}

\subsubsection{Multicollinearity}

The VIF value for all variables from the business owner's education, company age, accounting training and information technology showed greater than the tolerance value. With a VIF value greater than the tolerance value, the analyzed data is free from multicollinearity. 


\subsubsection{Autocorrelation}

Table 1 show in the autocorrelation test Durbin Watson value.

Table 1. Autocorrelation

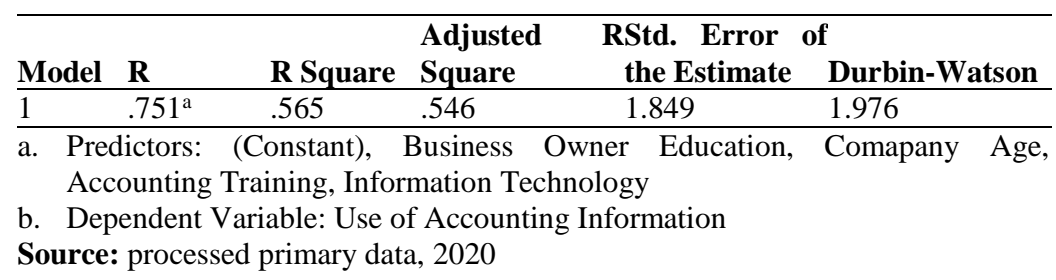

The Durbin Watson value is 1.976 , this value when seen in the Du and Dw tables is greater, so that with a larger Dw value it can be said that this analysis data is free from autocorrelation.

\subsubsection{Heteroscedasticity}

Heteroscedasticity testing is performed by plotting the residuals against the anticipated values of the standardized dependent variable on a Scatterplot (distribution path). As can be seen in the diagram above, the point distribution does not follow a specific pattern or path, implying that heteroscedasticity does not exist or, in other words, homoscedasticity does. In this model, traditional heteroscedasticity assumptions are met, resulting in a model that is heteroscedasticity-free.

\subsubsection{Normality}

The Normal P-P Plot graphic below shows the results of the normality test. It's worth noting that the normality assumption referred to in the standard OLS assumption refers to the residual (data) created by a normally distributed linear regression model, not the independent or dependent variable. The distribution of points in the graphic can be used to determine if a (data) residual is normally distributed or not using the Normal P-P Plot technique. The residual (data) is considered to be normally distributed if the distribution of the points is close to or dense on a straight line (diagonal), but it is not normally distributed if the distribution of the points is distant from the line.

Because the distribution of points in the Normal P-P Plot image above is near to a straight line, the residual (data) can be assumed to be normally distributed. The OLS technique yields findings that are consistent with traditional linear regression assumptions.

\subsubsection{Model feasibility test}

\subsubsection{Test of the reliability of the model (test $f$ )}

The model reliability test, also known as the model feasibility test or the F test (some also refer to it as the simultaneous model test), is the first step in determining whether or not a regression model is practicable. The term "eligible" ("reliable") refers to the estimated model's suitability for explaining the influence of the independent variables on the dependent variable. 
The F test gets its name from the F distribution, which has testing criteria that are similar to One Way Anova.

The F test results can be seen in the table test of the model's reliability show in Table 2. test $\mathrm{f}$ below. The value of the prob. The number of Fs is displayed in the last column (sig.)

Table. 2. Test of the reliability of the model (test $\mathrm{f}$ )

\begin{tabular}{lllllll}
\hline Model & & Sum of Squares & df & Mean Square & F & Sig. \\
\hline 1 & Regression & 424.515 & 4 & 106.129 & 31.338 & $.000^{\mathrm{b}}$ \\
& Residual & 321.725 & 95 & 3.387 & & \\
& Total & 746.240 & 99 & & & \\
\hline
\end{tabular}

a. Dependent Variable: Use of Accounting Information

b. Predictors: (Constant), Business Owner Education, Comapany Age, Accounting Training, Information Technology

Source: processed primary data, 2020

The value of the prob. The value of F count (sig.) in the table above is 0.000 , which is less than the 0.05 significance level, indicating that the estimated linear regression model is appropriate for explaining the effect of accounting information on the development of information technology.

\subsubsection{Regression coefficient test (test)}

The purpose of the t test in multiple linear regression is to see if the parameters (regression coefficients and constants) used to estimate the equation / multiple linear regression model show in Table 3 are valid. The aim is that these factors can explain how independent variables influence the dependent variable.

Table. 3. Result of Multiple Regression Test

\begin{tabular}{llll}
\hline No & Variable & T count & Sig P Value Regression Test's Result \\
\hline 1 & Owner Education & 4.580 & .000 \\
2 & Company Age & -2.163 & .033 \\
3 & Accounting Training & 6.239 & .000 \\
$4 \quad$ Information Technology & 1.579 & .001 \\
\hline Constant = 929 \\
Adjusted R Square = 0.551 \\
Source: processed primary data, 2020
\end{tabular}

The $\mathrm{t}$ test, like the F test, can be easily formed conclusions with the help of the SPSS application. If the value of prob. $t$ count (SPSS output shown in column sig.) is less than the error level (alpha) 0.05 (determined), the independent variable (from the $t$ count) has a significant effect on the dependent variable, whereas if the value of prob. $t$ count is greater than the error rate of 0.05 , the independent variable has no significant effect on the dependent variable. The $t$ count of the four independent variables (owner education, company age, accounting training, and information technology) is 0.001 , which is less than 0.05 , indicating that the four independent variables have a significant effect on the variable use of accounting information at alpha $5 \%$, or in other words, the four independent variables have a significant effect on the variable use of accounting information. 


\subsubsection{Coefficient determination}

The coefficient of determination show in Table 4 explains the variation in independent variable influence on the dependent variable. It's also known as the fraction of all independent factors' influence on the dependent variable. The R-Square value or the Adjusted R-Square can be used to calculate the coefficient of determination.

Table. 4. Coefficient Determination

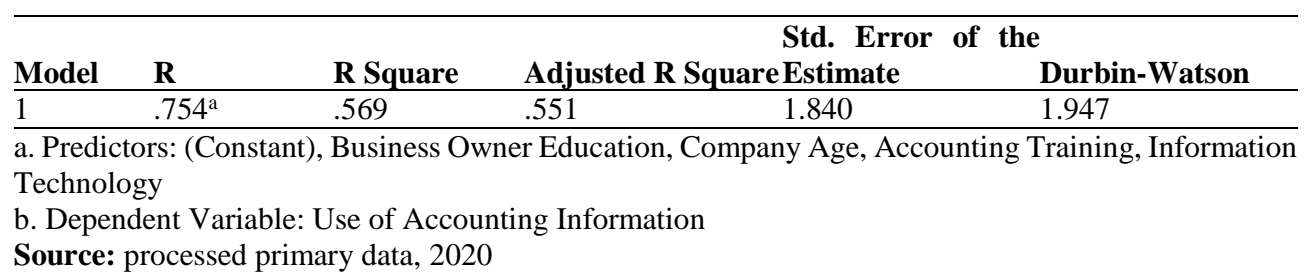

The $\mathrm{t}$ test, like the F test, can be easily formed conclusions with the help of the SPSS application. If the value is doubtful, If the t count (SPSS output in column sig.) is less than the error level (alpha) 0.05 (specified), the independent variable (from the $t$ count) has a significant effect on the dependent variable, however if the value of prob. When the $t$ count exceeds the error rate of 0.05 , the independent variable is said to have no effect on the dependent variable. The value of the prob. The t count of the four independent variables (owner education, company age, accounting training, and information technology) is 0.001 , which is less than 0.05 , indicating that the four independent variables have a significant effect on the variable use of accounting information at alpha $5 \%$, or in other words, the four independent variables have a significant effect on the variable use of accounting information.

The Adjusted R Square value of 0.551 obtained from this research reveals that the factors employed in this investigation have a 55.1 percent effect, while the remaining 44.9 percent is influenced by variables outside of this study. Meanwhile, the $\mathrm{R}$ value of 0.754 suggests that there is a substantial correlation between all of the variables in this study.

\subsection{Discussion}

The first hypothesis, as shown in table 4, argues that the owner's degree of education has a beneficial impact on the usage of accounting information in supported small and medium firms. This suggests that the owner's high degree of education has an impact on how accounting data is used by MSME owners. Owner education, company size, company age, and accounting training all have a beneficial impact on accounting data utilization [9].

The second hypothesis, as indicated in table 4 , argues that business age has a beneficial impact on the usage of accounting data in supported small and medium firms. This indicates that the company's age, as measured by the number of years it has been in business / the number of years it has been in business (MSME), has an impact on the usage of accounting data required by the UMKM's owner. Owner education, company size, company age, and accounting training all have a beneficial impact on accounting data utilization [9]. The amount of time spent on business has an impact on how much accounting data is used. The level of accounting information preparation and use is unaffected by the company's age [10].

The third hypothesis states that accounting training has a positive effect on the use of accounting information in supported small and medium enterprises, as shown in table 1 . This 
means that accounting understanding is proxied by increased understanding is good for MSMEs because making financial reports according to SAK can make it easier for companies. , such as knowing the company's performance and wealth. The ability to understand both meaning and meaning in studying a material is understanding [11]. Accounting training is considered to influence the use of accounting data if a high frequency of accounting training is accompanied by a high use of accounting data in business activities. This is because accounting education is thought to have the potential to improve MSME players' perceptions of financial management. Accounting education has an impact on how accounting data is used [1].

As stated in table 1, the fourth hypothesis states that information technology has a favorable impact on the usage of accounting data in supported small and medium enterprises. This indicates that information technology has a considerable positive impact on SMEs' utilization of accounting data. owner. Work may be completed on time when SMEs use IT for business operations, and IT users can compare pricing with competitors, continue to innovate their products, and compare prices with competitors. Information technology has a favorable impact on accounting data usage [12]. Accounting technology has an impact on the commercial success of MSMEs' superior products [13].

\section{Conclusion}

From the analysis, it is found that business owners, accounting training, and information technology have an influence on the use of accounting information in salt farmer businesses in coastal areas of Rembang Regency. There is one variable that has the opposite effect on the use of AIS, namely the age of the company. For further researchers, it is hoped that it can expand the object of research and add research variables related to the use of accounting information for small and medium micro enterprises.

\section{Acknowledgement}

Thank you very much to STIE YPPI Rembang, and all those who have helped the completion of this article.

\section{References}

[1] D. Efriyenty, “Analisis Faktor-Faktor Yang Mempengaruhi Penggunaan Informasi Akuntansi Pada Umkm Kota Batam,” J. Bisnis Terap., vol. 4, no. 1, pp. 69-82, 2020.

[2] H. Erna, "Analisis Faktor-Faktor yang Mempengaruhi Penggunaan Informasi Akuntansi Pada Usaha Mikro, Kecil dan Menengah (UMKM),” J. Ilmu Manaj., vol. 1, no. 2, pp. 43-66, 2017.

[3] G. T. Solovida, "Analisis Faktor-Faktor Yang Mempengaruhi Penyiapan Dan Penggunaan Informasi Akuntansi Pada Perusahaan Kecil Dan Menengah Di Jawa Tengah,” Tesis. Universitas Diponegoro. pp. 1-77, 2003.

[4] D. R. Sriwahyuni, Fatahurrazak, and I. L. S. Munthe, "Faktor Faktor yang Mempengaruhi Penggunaan Informasi Akuntansi pada Usaha Mikro, Kecil dan Menengah (UMKM) yang Ada di Kota Tanjungpinang," Artik. Ilm. 
[5] K. Meiliana, "Analisis Penggunaan Sistem Informasi Akuntansi pada Usaha Kecil DAN menengah di Yogyakarta,” Artikel, pp. 1-16, 2016.

[6] I. Ghozali, Aplikasi Analisis Multivariate dengan Program IBM SPSS 25. Semarang: Universitas Diponegoro, 2018.

[7] G. Damodar, Dasar-Dasar Ekonometrika, 5th ed. Jakarta: Salemba Empat, 2013.

[8] Y. A. Nugroho, It's Easy Olah Data dengan SPSS. Yogyakarta: Skripta Media Creative, 2011.

[9] L. D. Sitoresmi and Fuad, "Faktor-Faktor Yang Mempengaruhi Penggunaan (Studi Pada Kub Sido Rukun Semarang )," Diponegoro J. Account., vol. 2, no. 3, pp. 1-13, 2013.

[10] E. Astuti, "Pengaruh Karakteristik Internal Perusahaan Terhadap Penyiapan dan Penggunaan Informasi Akuntansi Perusahaan Kecil dan Menengah di Kabupaten Kudus," Universitas Diponegoro, 2007.

[11] R. Meidiyustiani, "Pengaruh Pendidikan Pemilik, Pemahaman Akuntansi, dan Motivasi Pemilik Terhadap Penerapan Standar Akuntansi Keuangan Untuk Entitas Tanpa Akuntabilitas Publik (SAK ETAP) (Studi Empiris: Perusahaan Kecil dan Menengah di Kota Tangerang),” Accounthink J. Account. Financ., vol. 1, no. 01, pp. 13-27, 2016.

[12] C. F. Jansen, J. Morasa, and A. Wangkar, "Pengaruh Penggunaan Teknologi Informasi Dan Keahlian Pemakai Terhadap Kualitas Informasi Akuntansi (Studi Empiris Pada Pemerintah Kabupaten Minahasa Selatan),” Going Concern J. Ris. Akunt., vol. 13, no. 04, pp. 63-71, 2018.

[13] H. Fathul Aminudin Aziz and H. Tri Utami, "The Influence of the Use of Accounting Information and Information Technology on the Success of Business Performance (A Survey on Micro, Small and Medium Enterprises (MSMEs) of Superior Products in Banyumas Regency)," KnE Soc. Sci., vol. 3 , no. 13 , p. 1073, 2019. 